\title{
Rethinking Assignor Estoppel ${ }^{1}$
}

\author{
Mark A. Lemley ${ }^{2}$
}

As patents have become increasingly important in society, we have focused more attention on the problem of bad patents. The Supreme Court and the Federal Circuit have repeatedly emphasized the public interest in testing the validity of patents, weeding out patents that should not have been issued. And Congress has created a number of new mechanisms to make it quicker and easier to identify and eliminate invalid patents.

But there is one important group of people the law systematically prevents from challenging bad patents. Curiously, it is the very group patent law is supposed to support: inventors themselves. The century-old doctrine of assignor estoppel precludes inventors who file patent applications from later challenging the validity or enforceability of the patents they receive. The stated rationale for assignor estoppel is that it would be unfair to allow the inventor to benefit from obtaining a patent and later change her tune and attack the patent when it benefits her to do so. ${ }^{3}$ The Supreme Court has traditionally disfavored the doctrine, reading it narrowly. But the Federal Circuit has expanded the doctrine in a variety of

1 (C) 2016 Mark A. Lemley.

2 William H. Neukom Professor, Stanford Law School; partner, Durie Tangri LLP. Thanks to Rochelle Dreyfuss, Ed Fein, Rose Hagan, Tim Holbrook, Orly Lobel, Lisa Ouellette, Jim Pooley, Greg Reilly, Ted Sichelman, and participants at the California State Bar Employment and IP conference, the University of San Diego patent conference, and a public lecture at the University of Houston for comments on an earlier draft and to Madeleine Laupheimer for research assistance.

3 See, e.g., Diamond Scientific Co. v. Ambico, Inc., 848 F.2d 1220, _ (Fed. Cir. 1988). I discuss this rationale in more detail in Part I. 
dimensions, and applied it even when the benefit to the inventor is illusory. Further, the doctrine misunderstands the role of inventor-employees in the modern world.

More important, the expansive modern form of assignor estoppel interferes substantially with employee mobility. Inventors as a class are put under burdens that we apply to no other employee. If they start a company, or even go to work for an existing company in the same field, they will not be able to defend a patent suit from their old employer. The result is a sort of partial noncompete clause, one imposed without even the fiction of agreement and one that binds anyone the inventor comes in contact with after leaving the job. Abundant evidence suggests that noncompetes in general retard innovation and economic growth, ${ }^{4}$ and several states prohibit them outright, while all others limit them. ${ }^{5}$ But assignor estoppel is a federal law doctrine that overrides those state choices.

It is time to rethink the doctrine of assignor estoppel. In Part I, I describe the doctrine, its rationale, and how it has expanded dramatically in the past 25 years. In Part II, I argue that the doctrine is out of touch with the realities of both modern inventing and modern patent law, and that it interferes with both the invalidation of bad patents and the goal of employee mobility. Should the Supreme Court take up the doctrine, it is unlikely to survive in its current form. Finally, in Part III I explore whether the doctrine can and should be saved in a more limited form.

4 See infra notes ___ and accompanying text.

5 See, e.g., Robert P. Merges et al., Intellectual Property in the New Technological Age ch. 2 (6 ${ }^{\text {th }}$ ed. 2012) (discussing the various state rules). 


\section{The Growth of Assignor Estoppel}

\section{A. The Genesis of the Doctrine}

The equitable doctrine of assignor estoppel originated early in the history of patent law. ${ }^{6}$ It was developed to prevent a party who sells a patent to another from later trying to undermine the value of the thing she sold by challenging its validity. ${ }^{7}$ As originally applied, the doctrine generally applied between two parties that entered into a patent assignment agreement at arm's length. ${ }^{8}$

The Supreme Court considered the doctrine for the first time in $1924 .^{9}$ That case involved what would become a common situation: an employee ( $\left.\mathrm{O}^{\prime} \mathrm{Conor}\right)$ who assigned an invention to his employer, Westinghouse, during the course of employment. The invention involved a two-step process for making insulation. When O'Conor left to found a competing company, Formica, that used a somewhat different one-step insulation-making process, Westinghouse sued him and his new company for patent infringement. In response, he challenged the validity of the patent. The Court took the position that a party who sells a

6 The first case to apply the doctrine was an English case, Oldham v. Langmead, 2 Wils. 374 (1789). See also Hayne v. Maltby, 3 T.R. 438, 100 Eng. Rptr. 665 (1789) (characterizing Oldham as analogous to estoppel by deed in real property).

7 Lara J. Hodgson, Assignor Estoppel: Fairness at What Price?, 20 Santa Clara Comp. \& High Tech. L.J. 797, 800 (2004).

8 See, e.g., Oldham v. Langmead, 2 Wils. 374 (K.B. 1789).

9 Westinghouse Elec. \& Mfg. Co. v. Formica Insulation Co., 266 U.S. 342, 349 (1924). Cf. Kinsman v. Parkhurst, 59 U.S. (18 How.) 289, 293 (1855) (holding that a party who had promised to pay royalties in a joint ownership agreement for the patent could not avoid its contractual obligation by claiming invalidity, because nothing in the license contract turned on the validity of the patent). 
patent to a buyer should not be able to thereafter challenge the title to that patent. The Court drew an analogy to real property law, in which the doctrine of "estoppel by deed" precluded those who sold land from thereafter challenging the validity of the deed they had conveyed for value, and to similar estoppel provisions that operate between to prevent landlords from denying the validity of their leases to tenants. ${ }^{10}$

Nonetheless, the Court explained that while the inventor who assigned the patent to his employer could not assert the invalidity of the patent as a whole, he was free to challenge the scope of that patent:

But the state of the art may be used to construe and narrow the claims of the patent, conceding their validity. The distinction may be a nice one but seems to be workable. Such evidence might not be permissible in a case in which the assignor made specific representations as to the scope of the claims and their construction, inconsistent with the state of the art, on the faith of which the assignee purchased; but that would be a special instance of estoppel by conduct. We are dealing only with the estoppel of an assignment based on the specifications and claims without special matter. ${ }^{11}$

The Court reasoned that while the inventor had given the company the right to his invention, he had not agreed to the scope of any particular claim. The Court was careful to permit challenges to the scope of the patent even when the assignor had actually assigned an issued patent. But in Westinghouse, as in most employment contexts, O'Conor assigned a new invention that was not yet even the basis of a patent application, much less a patent. In that instance, the Court suggested that the ability to challenge the patent was correspondingly greater:

10 Westinghouse, 266 U.S. at _.

11 Id. at _. 
We can well be clear, however, that if it is proper to limit the estoppel available for an assignee after patent as against his assignor by reference to the state of the art, a fortiori is such reference relevant where the estoppel is sought by the assignee before patent. ${ }^{12}$

Notably, the Court's discussion of limiting estoppel "by reference to the state of the art" seems to contemplate not just noninfringement arguments, but the invalidation or at least reformation of claims that overreach. While the Court's language sounds to modern ears like claim construction, in 1924 claim construction was bound up with validity, because the Court had and applied a doctrine of "undue breadth" to narrow or invalidate overbroad claims. ${ }^{13}$ Indeed, the Court's ultimate holding was that O'Conor could challenge the Westinghouse patent claims that did not require the two-step process O'Conor had actually invented:

We are clear then that the estoppel of the eleventh and twelfth claims against O'Conor does not extend to a single step process such as he has participated in as partner, stockholder or officer; and if it does not affect him, a fortiori does it not affect the respondent company. ${ }^{14}$

O'Conor might not be permitted to challenge patent claims that he himself invented, but he was entitled to challenge the validity of claims that reached beyond what he had actually disclosed or assigned to Westinghouse.

Because the assignor estoppel claim in Westinghouse actually failed - Westinghouse couldn't prevent O'Conor from challenging the validity of the only claims that actually read on O'Conor's new business - the Court did not address two important questions:

\footnotetext{
12 Id. at

13 See, e.g., In re Borkowski, 422 F.2d 904 (C.C.P.A. 1971); In re Frilette, 423 F.2d 1397 (C.C.P.A. 1970). One commentator notes that the doctrine is "disfavored" today. Brian P. O'Shaughnessy, The False Inventive Genius: Developing a New Approach for Analyzing the Sufficiency of Patent Disclosure in the Unpredictable Arts, 7 Fordham Intell. Prop., Med. \& Ent. L.J. 147, 172 (1996).

14

Westinghouse, 262 U.S. at _.
} 
This result makes it unnecessary for us to consider the objections that the Formica Company is not affected by an estoppel which would operate against O'Conor, or that the alleged nominal character of the consideration moving to O'Conor cannot support an estoppel. ${ }^{15}$

In Scott Paper v. Marcalus Manufacturing, ${ }^{16}$ the Court's most recent foray into the doctrine, it further limited assignor estoppel. That case, unlike Westinghouse, involved an employee, Marcalus, who assigned an actual patent rather than an application to his employer. When the new company he started was sued for infringement of that patent, he argued that the new company was practicing a prior art patent that had already expired. Marcalus conceded that it could not challenge the validity of the particular improvement its founder had made, but argued that estoppel did not prevent him from using the new-found prior art to narrow the scope of the patent, in this case into nonexistence. Scott, the plaintiff and original employer, sought to apply the doctrine of assignor estoppel, but the Court refused, holding that the doctrine did not "foreclose the assignor of a patent from asserting the right to make use of the prior art invention of an expired patent, which anticipates that of the assigned patent." 17 The Court supported its conclusion by reference to public policy, holding that the application of assignor estoppel in this case is incompatible "with the patent laws which dedicate to public use the invention of an expired patent." ${ }^{18}$ But it also seems to have been motivated by the fact that Marcalus was unaware of the prior art patent when he assigned his invention, so he was not engaged in deliberate deception.

\footnotetext{
15 Id.

${ }^{16} 326$ U.S. 249 (1945).

17 Id. at 257.

18 Id. at 258.
} 
The result was that by 1945, the doctrine of assignor estoppel was quite limited, and seemed to apply only to actual representations made by inventors, not to validity challenges based on the prior art. Indeed, the Supreme Court in Lear held that the general rule of assignor estoppel had been undermined by Westinghouse and Scott. ${ }^{19}$ In the wake of Lear, "assignor estoppel became a significantly limited doctrine that the Supreme Court no longer favored." ${ }^{20}$

\section{B. Assignor Estoppel in the Federal Circuit}

The Federal Circuit has expanded assignor estoppel dramatically from its roots. The expansion takes several forms. Among others, the Federal Circuit has resolved both of the questions the Supreme Court left open.

First, the Federal Circuit has held that not just the patent assignor but anyone in privity with that assignor is subject to the estoppel. The court began by applying assignor estoppel to a company actually formed and run by the inventor. ${ }^{21}$ But it quickly expanded the scope of the estoppel beyond assignor-founded companies. In Shamrock Technologies v. Medical

Sterilization, ${ }^{22}$ the court extended estoppel to the inventor's new employer "when the assignor is so actively involved in the allegedly infringing activity as to be more than a 'mere employee.'"23 Shamrock contemplated a multi-factor test that evaluated the closeness of the

19 Lear, Inc. v. Adkins, 395 U.S. 653 (1969).

20 Donald Steinberg \& David Chavous, Supreme Court Review of Patent Cases: What Will Follow eBay, Medlmmune, and KSR?, 8 J. High Tech. L. 185, _ (2010).

21 Diamond Scientific Co. v. Ambico, Inc., 848 F.2d 1220, _ (Fed. Cir. 1988) ("The estoppel also operates to bar other parties in privity with the assignor, such as a corporation founded by the assignor.").

22903 F.2d 789 (Fed. Cir. 1990).

23 Id. at _. 
relationship between the inventor and the person asserting the defense, but in practice the court has cast a wide privity net. The list of those barred from challenging a patent includes not only officers and directors of the new company, but even line employees or scientists if they are themselves working on the allegedly infringing products. Indeed, the courts have held that privity extends to circumstances in which "the ultimate infringer availed itself of the inventor's knowledge and assistance to conduct infringement," regardless of the employee's position. ${ }^{24}$ And in 2016, the Federal Circuit applied the privity doctrine to bar a challenge by a company that had already developed its product before hiring the inventor, despite the facts that the inventor had minimal financial interest in the company and had indeed been hired in part to design around the patent and make sure the hiring company was avoiding infringement. ${ }^{25}$ Indeed, the Federal Circuit has extended privity beyond the assignor's new employer. In Mentor Graphics v. Quickturn Design Systems, ${ }^{26}$ the court extended assignor estoppel from a corporate parent to its subsidiary even though the subsidiary was not even purchased until after the assignment was complete. ${ }^{27}$ In dictum, the court suggested that even being a minority shareholder could be sufficient to establish privity. ${ }^{28}$ In Checkpoint Systems v. All-Tag Security, ${ }^{29}$ the court held open the possibility that estoppel could apply to a defendant run by an individual who formerly worked for a company which had hired the inventor as an

\footnotetext{
24 Intel Corp., 946 F.2d at 839.

25 MAG Aerospace Indus. v. B/E Aerospace, Inc., __ F.3d__ (Fed. Cir. Mar. 23, 2016).

26150 F.3d 1374 (Fed. Cir. 1998).

27 Id. at _.

28 Id. at _ (citing Shamrock Technologies, 903 F.2d at 789) ("Even a party that owns less than a majority of a company's stock can still exercise effective control over the company's operations.").

29412 F.3d 1331 (Fed. Cir. 2005).
} 
independent contractor, obtained a patent assignment from that contractor, and later sold the company (with patent) to another company which in turn was bought by plaintiff Checkpoint. ${ }^{30}$ And in Intel Corp. v. International Trade Commission, ${ }^{31}$ the court extended assignor estoppel to the assignor's joint venture partner where the joint venturer, even though an independent company, was intimately involved with the joint development of the technology accused of infringement. ${ }^{32}$ In the course of doing so, the court said that assignor estoppel "bars a challenge by any party in privity with the assignor.." ${ }^{33}$ It has said that whether privity exists depends on the closeness of the relationship to the assignor. ${ }^{34}$ Notably, however, the Federal Circuit has never found a defendant not to be in privity and therefore bound by estoppel.

Second, the Federal Circuit has flatly rejected the argument that assignor estoppel should be limited to those who actually sell a patent for revenue. While the court has repeatedly articulated the rationale for assignor estoppel as "the unfairness and injustice of permitting a party to sell something and later to assert that what was sold is worthless," ${ }^{\prime 35}$ it doesn't actually require a sale. The court has applied the doctrine in a wide array of employeeassignment cases, even when the assignment of an idea is automatic and done without any

30 Id. at

31946 F.2d 821 (Fed. Cir. 1991).

32 Id. at _.

33 Id. That language has been picked up by other cases as the standard formulation. See, e.g., Checkpoint Systems, 412 F.3d 1331.

34 Mentor Graphics, 150 F.3d at _ ; Shamrock, 903 F.2d at 789.

35 Mentor Graphics, 150 F.3d at _ ; accord Pandrol USA LP v. Airboss Railway Prods., 424 F.3d 1161 (Fed. Cir. 2005) ("the assignor will not be allowed to say that what he has sold as a patent was not a patent."). 
compensation to the employee. Indeed, in Carroll Touch, Inc. v. Electro Mechanical Systems, ${ }^{36}$ the district court had refused to apply assignor estoppel against Lazarevich, an employee coinventor who had played only a minimal role in the invention, received no compensation for the invention or the assignment, and did not realize when he signed a document entitled "Declaration and Power of Attorney" that he was assigning away his rights in the invention. ${ }^{37}$ The Federal Circuit reversed, holding that it was an abuse of discretion to refuse to apply assignor estoppel to Lazarevich. The court held that simply being an employee was compensation sufficient to trigger estoppel, and that he should have read the document carefully before he signed it. ${ }^{38}$ Other opinions have gone even further, suggesting that the doctrine applies whether or not the inventor actually received any value in exchange for the assignment ${ }^{39}$ and even when the inventor feared losing his job if he didn't file the patent application. $^{40}$

The Federal Circuit has expanded assignor estoppel in other respects as well. First, it has applied the doctrine even when the patent plaintiff wrote the patent claims in ways that were substantially broader than the inchoate idea the assignor conveyed. In Diamond Scientific, for example, the court applied assignor estoppel even though the assignee-plaintiff amended the claims after the assignment. The court reasoned that "the inventor assigned the $36 \quad 15$ F.3d 1573 (Fed. Cir. 1993).

37 Id. at _.

38 Id. at _. The court clearly didn't believe some aspects of Lazarevich's testimony, noting that he had testified in a different lawsuit that he was a "principal inventor." Id. But disbelief of a witness seems a surprising reason for an appellate court to reverse a district court's assessment under an abuse of discretion standard.

39 Pandrol, 424 F.3d at _ ("assignor estoppel prevents an assignor from asserting that its own patent, for which it may have received value upon assignment, is invalid and worthless.").

40 Shamrock Tech., Inc. v. Med. Sterilization, Inc., 903 F.2d 789, 794 (Fed. Cir. 1990). 
rights to his invention, irrespective of the particular language in the claims describing the inventions when the patents were ultimately granted.." ${ }^{41}$ The court went even further in General Foods Corp. v. Studiengesellschaft Kohle $\mathrm{mbH}^{42}$ applying assignor estoppel even though the assignee filed a continuation-in-part application and added a feature not disclosed by the assignor at all. ${ }^{43}$ The Federal Circuit has cited Westinghouse to permit the defendant to "introduce evidence of prior art to narrow the scope of the claims of the patents" ${ }^{44}$ when the claims have changed since the assignment, which is what the Court actually did in Westinghouse. But that promise is likely illusory in modern patent jurisprudence, which has all but eliminated the ability to argue that claims should be narrowed to avoid invalidating prior art. ${ }^{45}$ And some commentators read the Federal Circuit cases as limiting noninfringement arguments based on practicing the prior art as well. ${ }^{46}$

Second, the Federal Circuit has expanded assignor estoppel by circumventing attempts by the parties to contract around the doctrine. In theory, an assignment only raises a presumption of assignor estoppel, and that presumption can be rebutted by "an express

41848 F.2d at _. In doing so, the Federal Circuit undermined the analogy to estoppel by deed in real property, which is necessarily bound to the legal document that defines the rights. Estoppel by deed would not justify an assignment of rights in a document that has not yet been created and may later be modified. Hodgson, supra note _, at 819-20.

42972 F.2d 1272 (Fed. Cir. 1992).

43 Id. at _.

44 Diamond Scientific, 848 F.2d at _.

45 Phillips v. AWH Corp., 415 F.3d 1303 (Fed. Cir. 2005) (en banc) (noting that the doctrine that claims should be construed to preserve their validity has not been read broadly, and treating it as a last resort).

46 Schuurman et al., supra note _, at 724 (arguing that assignor estoppel also limits "the assignor's right to assert a defense of noninfringement. While the assignor may be allowed to use the state of the art to construe or narrow claims, and thereby perhaps avoid infringement, he cannot use the prior art to prove what he assigned was worthless."). 
reservation by the assignor of the right to challenge the validity of the patent or an express waiver by the assignee of the right to assert assignor estoppel." ${ }^{47}$ But the Federal Circuit requires "extraordinary circumstances" to avoid application of estoppel, ${ }^{48}$ and in practice they do not find such a waiver even in circumstances in which it seems pretty clear that the parties did not intend to disadvantage the assignor. In Acoustical Design, Inc. v. Control Electronics Co., ${ }^{49}$ for instance, the court applied the doctrine even though the assignor took a license back to the patent, a circumstance that the Supreme Court nearly half a century ago said should permit patent challenges. ${ }^{50}$ And in Q.G. Products v. Shorty, Inc., ${ }^{51}$ the inventor, Simon, cofounded defendant Shorty and assigned his patent to the company. When Simon had a falling out with the other two co-owners of Shorty, the company assigned the patent back to Simon in exchange for the return of the money he had originally been given. The Federal Circuit nonetheless held that the company that received the initial assignment and then unwound the transaction by giving the patent back to Simon was barred by assignor estoppel from challenging the validity of the patent, since the unwinding of the transaction technically involved an assignment back to the original inventor! $!^{52}$

Finally, the Federal Circuit has, albeit inconsistently, expanded assignor estoppel beyond preventing assignors from defending patent suits based on invalidity. Courts have read it to prevent antitrust challenges based on Walker Process claims of fraudulent acquisition of a

\footnotetext{
47 Mentor Graphics, 150 F.3d at

48 Id.

49932 F.2d 939 (Fed. Cir. 1991).

50 Lear, Inc. v. Adkins, 395 U.S. 653 (1969).

51992 F.2d 1211 (Fed. Cir .1993).

52 Id. at
} 
patent. $^{53}$ The Federal Circuit has forbidden assignors from testifying about the invention in ways that might question its validity. ${ }^{54}$ In other words, the doctrine has been applied not only to preclude a legal argument by a party but to prevent the introduction of relevant evidence from inventors by defendants who are not themselves subject to estoppel. ${ }^{55}$

The result of these rulings has been a dramatic expansion of assignor estoppel. The Federal Circuit applies the doctrine liberally and construes exceptions so narrowly that they are worthless in practice, even in factual circumstances far removed from the original basis of the doctrine. The power of assignor estoppel at the Federal Circuit is so great that the court has never once refused to apply the doctrine. ${ }^{56}$

53 Eagle Comtronics, Inc. v. Ne. Filter Co., 1991 U.S. Dist. LEXIS 16965 at *3 (N.D.N.Y. Nov. 21, 1991). 54 Pandrol, 424 F.3d at _ ("assignor estoppel prevents an assignor from asserting that its own patent, for which it may have received value upon assignment, is invalid and worthless.").

55 Pandrol, 424 F.3d at _ (affirming decision "to bar an assignor from testifying against the validity of its own patent"). But see Checkpoint, 412 F.3d at _ ("it would be unwise to fashion an across-the-board rule barring testimony ... A party, such as Sensormatic, that is not barred by assignor estoppel from challenging the validity of the patent, should be able to at least proffer all otherwise admissible evidence in support of its case.").

Some district courts have created an exception where the assignee engages in inequitable conduct, on the theory that the assignor should not be held responsible for the assignee's subsequent lies to the PTO. See, e.g., HWB, Inc. v. Braner, Inc., 1994 WL 447530, at *6-7 (N.D. III. Aug. 16, 1994); Med. Designs, Inc. v. Med. Tech., Inc., 786 F. Supp. 614, 618 (N.D. Tex. 1992).

56 The court has distinguished challenges to patent validity after an assignment, which are estopped, from challenges to the validity of the contract itself, which are permitted. University of West Virginia $v$. VanVoorhies, 278 F.3d 1288 (Fed. Cir. 2002). The court drew this distinction on the dubious ground that assignor estoppel "is based on the evident unfairness of one receiving compensation for the transfer of an asset and then asserting that the asset has no value. There is no corresponding unfairness in a challenge to the validity of a contract." Id. at _. The court did not explain why accepting money in exchange for a contract promise, then repudiating the contract, is any less unfair than accepting money in exchange for a patent assignment, then repudiating the patent.

The court has also held that assignor estoppel does not bind unrelated non-parties even if a codefendant is so bound. Checkpoint, 412 F.3d at _. But in that case, the court ultimately remanded for the application of assignor estoppel by the district court. 


\section{The Problems With Assignor Estoppel}

\section{A. The Dubious Rationales for Assignor Estoppel}

Courts have articulated two related rationales for the doctrine: “(1) to prevent unfairness and injustice, and (2) to prevent one benefiting from his own wrong." ${ }^{57}$ Those two rationales are essentially the same, though. The idea is that it is unfair for me to sell you something, take the money, and then reveal that the thing I sold you was actually worthless. I am depriving you of your expectation, and I am profiting from that deceit. ${ }^{58}$

The premises that implicitly underlie that rationale are, first, that I sold you something for profit; second, that I knew that the thing I was selling you was worthless; and third, that you relied on my explicit or implicit representation that it was valuable rather than establishing that for yourself. Each of those premises can be questioned in the modern, expansive vision of assignor estoppel.

The first premise is directly belied by the modern cases. The nineteenth-century vision of assignor estoppel was directed at people who themselves sold a patent for profit. But modern assignor estoppel no longer is. Not only does it reach companies that never made such a promise, it extends to patents that did not exist at the time of the deal. More important, assignor estoppel is regularly applied to bind employee-inventors on the basis of their assignment of the patent to their employers. But nothing about the modern employeeinventor suggests that they are selling their inventions to their employers for profit. Employees

57 Diamond Scientific, 848 F.2d at _. . Courts articulate two other justifications, id. but they are really just the analogies mentioned above to estoppel by deed and landlord-tenant law.

58 Mentor Graphics, 150 F.3d at _ ("This doctrine prevents the unfairness and injustice of permitting a party to sell something and later assert that what was sold is worthless."). 
are regularly required to assign all their inventions as a condition of employment. ${ }^{59}$ Those assignment agreements are standard-form contracts, usually presented to the employee on their first day of work, after they have quit their prior job and perhaps relocated. ${ }^{60}$ So they apply by definition to inventions that have not yet been made. Companies and universities impose them on all their employees, not just designated inventors; as a research assistant in law school, for instance, I was forced to assign all the inventions I might make during law school. And the employees are not normally paid extra in exchange for assigning their rights. Indeed, employees are sometimes compelled to disclose their inventions against their will so the employer can turn it into a patent. ${ }^{61}$ Even if they aren't, "[t]he signing of the [inventor's] declaration is a relatively perfunctory act, done long after the employer himself has decided to pursue a patent." ${ }^{62}$ Employees may sign an inventorship form even if they doubt the validity of the invention because they fear to lose their job if they don't. ${ }^{63}$ And if the employee can't or

59 Hodgson, supra note _, at 827-28. For an example of this ordinary phenomenon, see Shukh v. Seagate Tech., LLC, _ F.3d__ (Fed. Cir. Oct. 2, 2015). Before 2010, some employers required employees to sign an "agreement to assign" inventions they later made. But after the Supreme Court held that that agreement did not itself assign the rights, Trustees of Leland Stanford, Jr. University $v$. Roche Pharms., 563 U.S. 776 (2011), essentially all employers require preassignment of inventions.

60 Ubell, Assignor Estoppel: A Wrong Turn From Lear, 71 J. Pat. \& Trademark Ofc. Soc'y 26, 27 (1989).

61 In one notorious case, an employee who came up with an idea not directly related to his job and tried to sell it to his employer was sued and ordered to disclose the idea because the thoughts in his head belonged to the employer. The case (DSC Comm'ns v. Brown) is not reported, but discussions of it include Evan Ramstad, DSC Won't Pay a Penny for His Thoughts - Company Sues For Ownership of Employee's Idea, Wall St. J., July 14, 1997, at B4; Dale D. Smith, A Musing Affair: Who Owns Your Thoughts?, 44 Loy. (LA) L. Rev. 155 (1998).

62 Ubell, supra note__, at 28. The inventor's affidavit merely attests that to the best of his knowledge he is the original inventor of the subject matter of the application. An inventor is not required to search for prior art, and makes no warranty that the application in fact reflects a patentable invention. Hodgson, supra note _, at 822-23.

63 Id. ("The employee oftentimes feels compelled to execute the declaration and assignment forms because of his employment agreement or the desire to keep his job."). 
won't sign the agreement, the law since 2011 allows the company to apply for a patent in their name without their signature, simply by attesting that they were obligated to assign the invention. ${ }^{64}$ Employees who assign their inventions have no ownership or financial interest in any patents that result. ${ }^{65}$ The employer holds legal title to the invention even if it was assigned before it was made. ${ }^{66}$

The automatic assignment by employees also undermines the second and third premises that underlies assignor estoppel: the idea that an employee was defrauding the unsuspecting company by selling it something she knew to be worthless. That cannot be true if an employee is assigning her rights to patents that aren't yet written, and indeed to inventions that haven't even been made yet. Similarly, an employer that requires all its employees to disclose all their ideas and pre-assign them to the company cannot plausibly claim to have relied on some sort of implied promise by the employees that the inventions they disclose are valuable ones. ${ }^{67}$ Rather, in the words of the Sixth Circuit, the employee's assignment says little more than "Here, is my device; I do not know whether it is patentable, or, if it is, how broadly; take it, prosecute the patent application, and get what you can.."68

\footnotetext{
6435 U.S.C. $\$ 116$.

65 Shukh, _F.3d at _.

66 Filmtec Corp. v. Allied-Signal, Inc., 939 F.2d 1568, 1573 (Fed. Cir. 1991).

67 Lobel, Cognitive Property, supra note _, at 820.

68 Westinghouse Elec. \& Mfg. Co. v. Formica Insulation Co., 288 F. 330 (6 ${ }^{\text {th }}$ Cir. 1923), aff'd, 266 U.S. 342 (1924). But see Schuurman et al., supra note _, at 747 ("More often than not the employee-inventor does participate actively in the patent prosecution process. He is asked to prepare a disclosure for the patent attorney, is asked to review the specification and claims, and he is asked to review and advise on prior art, amendments, and arguments during prosecution."). As Schuurman et al. note, however, the Federal Circuit does not require "active participation" by the employee. Diamond Scientific, 848 F.3d at 1226.
} 
None of this is to say that there aren't circumstances in which an assignor might deceive a buyer by promising a valid patent and then going back on that promise. But the growth of assignor estoppel means that it now applies most of the time to cases in which the rationale for the doctrine simply doesn't apply.

\section{B. The Changing Nature of Validity Challenges}

While assignor estoppel has expanded dramatically over time, the nature of patent validity challenges has also changed, in a way that undermines many of the traditional justifications for assignor estoppel. Three such changes are particularly significant.

The death of licensee estoppel. First, since it last addressed assignor estoppel nearly a century ago, the Supreme Court has emphasized the importance of encouraging challenges to invalid patents. In a series of cases fifty years ago, the Supreme Court made clear that invalidating bad patents served not only a private but also a public interest. For that reason, the Court held that invalidation in one case prevented the patentee from asserting that patent in subsequent cases. ${ }^{69}$ Of greater significance for our purposes, the Court in Lear, Inc. v. Adkins

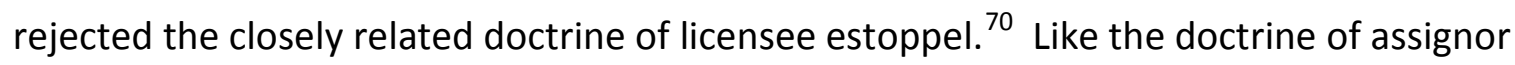
estoppel, the doctrine of licensee estoppel had drawn on real property analogies to preclude someone who took the benefit of a contract involving a patent from challenging the basis for that contract. In the case of licensee estoppel, it was the party who took a license rather than

69 Blonder-Tongue Labs. v . Univ. of Illinois Found., 402 U.S. 313 (1971).

70 Lear, Inc. v. Adkins, 395 U.S. 653 (1969). 
face suit that was estopped from later claiming that it did not need that license because the

patent was invalid. The Court rejected the doctrine, explaining that public policy favored challenges to patents:

[F]ederal law requires, that all ideas in general circulation be dedicated to the common good unless they are protected by a valid patent. ...

The decisive question is whether overriding federal policies would be significantly frustrated if licensees could be required to continue to pay royalties during the time they are challenging patent validity in the courts.

It seems to us that such a requirement would be inconsistent with the aims of federal patent policy. Enforcing this contractual provision would give the licensor an additional economic incentive to devise every conceivable dilatory tactic in an effort to postpone the day of final judicial reckoning. We can perceive no reason to encourage dilatory court tactics in this way. Moreover, the cost of prosecuting slow-moving trial proceedings and defending an inevitable appeal might well deter many licensees from attempting to prove patent invalidity in the courts. The deterrent effect would be particularly severe in the many scientific fields in which invention is proceeding at a rapid rate. In these areas, a patent may well become obsolete long before its 17-year term has expired. If a licensee has reason to believe that he will replace a patented idea with a new one in the near future, he will have little incentive to initiate lengthy court proceedings, unless he is freed from liability at least from the time he refuses to pay the contractual royalties. Lastly, enforcing this contractual provision would undermine the strong federal policy favoring the full and free use of ideas in the public domain. ${ }^{71}$

Further, the Court explained that preventing licensees from challenging patents would undermine that policy because licensees were often the people with the best knowledge of the patent and the strongest incentive to challenge it:

the equities of the licensor do not weigh very heavily when they are balanced against the important public interest in permitting full and free competition in the use of ideas which are in reality a part of the public domain. Licensees may often be the only individuals with enough economic incentive to challenge the

71 Id. at 669, 673-74. See also Scott Paper Co. v. Marcalus Mfg. Co., 326 U.S. 249 (1945) (holding that, in the words of Lear, "the policy of the patent laws would be frustrated if a manufacturer was required to pay for the use of information which under the patent statutes, was the property of all."). 
patentability of an inventor's discovery. If they are muzzled, the public may continually be required to pay tribute to would-be monopolists without need or justification. We think it plain that the technical requirements of contract doctrine must give way before the demands of the public interest in the typical situation involving the negotiation of a license after a patent has issued. ${ }^{72}$

The rationale for eliminating licensee estoppel is hard to square with the continued vitality of the closely-related doctrine of assignor estoppel. Indeed, the Lear Court read its own Westinghouse precedent as limited and indeed as perhaps allowing challenges to the validity of the patent. ${ }^{73}$ And before the creation of the Federal Circuit, at least one regional circuit had held that Lear spelled the death of assignor estoppel as well. ${ }^{74}$ While Lear does not expressly overrule assignor estoppel, it throws the whole doctrine into serious question. ${ }^{75}$

Nor is Lear an outlier or simply the product of a bygone age. The Supreme Court's recent decision in Kimble v. Marvel ${ }^{76}$ makes clear that the Court's view of challenges to invalid patents as serving the public interest is alive and well. It reaffirmed the policy basis behind Lear and the public interest in weeding out invalid patents. ${ }^{77}$

Changes in the Nature of Patent Validity Litigation. A second change in the law that affects assignor estoppel concerns the nature of patent validity challenges. The theory

\footnotetext{
72 Id. at 670-71.

73395 U.S. at 665.

74 See, e.g., Coastal Dynamics v. Symbolic Displays, Inc., 469 F.2d 79, 79 (9 ${ }^{\text {th }}$ Cir. 1972).

75 Cf. Amber L. Hatfield, Life After Death for Assignor Estoppel: Per Se Application to Protect Incentives to Innovate, 68 Tex. L. Rev. 251, 254 (1989) (“abolishing licensee estoppel, Lear also weakened assignor estoppel").

76135 S.Ct. 2401 (2015).

77 By contrast, some have worried that the Supreme Court's decision in Commil v. Cisco Sys., Inc., 135 S.Ct. 1920 (2015), reduces incentives for competitors to enter markets by challenging patents they believe to be invalid. Timothy Holbrook, The Supreme Court's Quiet Revolution in Induced Patent Infringement, Notre Dame L. Rev. _ (forthcoming 2016).
} 
underlying assignor estoppel is that an inventor is in best possession of the facts and therefore can assess whether or not she has in fact done something worthy of a patent. The inventor's implicit representation about those facts might be thought to bind her from later taking inconsistent positions. ${ }^{78}$ But most validity challenges in the modern world are not based on facts in the inventor's possession. One of the most inventor-specific doctrines, unenforceability by inequitable conduct, has all but disappeared as a result of Federal Circuit decisions limiting its scope. ${ }^{79}$ Invalidity for incorrect inventorship, another doctrine that may depend on the inventor's specific knowledge, was abolished outright in 2011 by the America Invents Act. ${ }^{80}$ So too was the best mode doctrine, which depended on the inventor's state of mind when filing a patent application. ${ }^{81}$ The most commonly asserted validity challenges today - patentable subject matter, obviousness, enablement, and indefiniteness - are all questions of law or at

78 Even that is questionable. In re Baker Hughes, Inc., 215 F.3d 1297 (Fed. Cir. 2000), provides a remarkable contrast to the doctrine of assignor estoppel. There, the court faced the reverse situation. Baker Hughes filed a reexamination request in the Patent and Trademark Office seeking to invalidate a competitor's patent. It persuaded the patent examiner to invalidate the patent, and then ended up owning the patent, at which point it sought to appeal the very decision it had persuaded the examiner to make. The Federal Circuit saw no quasi-estoppel problem with the patentee reversing position to argue for validity as opposed to arguing for invalidity: "The public interest lies in having valid patents upheld and invalid patents rendered invalid, and hence patents should be reexamined when a substantial question of patentability is raised." $I d$. at _. It is interesting that when it is validity rather than invalidity is at issue the Federal Circuit is perfectly happy to have parties change positions 180 degrees.

79 Therasense Inc. v. Becton, Dickinson \& Co., 649 F.3d 1276 (Fed. Cir. 2011) (en banc). One study found that Therasense and its progeny dramatically reduced the number of cases in which inequitable conduct is alleged. Robert D. Swanson, The Exergen and Therasense Effects, 66 Stan. L. Rev. 695 (2014).

8035 U.S.C. §116, which formerly provided for invalidity for improperly named inventors, now permits the correction of inventorship on the patent. Accord 35 U.S.C. $\$ 256$.

81 For a discussion of the curious way in which the AIA eliminated the best mode requirement for all practical purposes, see Lee Petherbridge \& Jason Rantanen, In Memoriam Best Mode, 64 Stan. L. Rev. Online 125 (2012). 
least mixed questions of law and fact. ${ }^{82}$ So too is claim construction, which defines the scope of the patent right and therefore determines its validity. ${ }^{83}$ And even the subsidiary questions of fact that underlie obviousness or enablement are questions about what the person having ordinary skill in the art would know or be able to do, not about anything the inventor knew or did. It might be reasonable to bind a non-lawyer inventor to factual representations about what she invented or what she disclosed in applying for the patent, but it seems much more of a stretch to say that the inventor should be bound to an understanding of what $K S R$ or Alice means as a matter of law or what an independent expert knows. ${ }^{84}$ True, there are some questions - co-inventorship, the existence of sales more than a year before filing a patent application - that may in some cases depend critically on facts uniquely within the possession of the inventor. ${ }^{85}$ And if the inventor made a representation to the PTO about those facts, it might make sense to bind the inventor to those representations. But that is the exception in modern patent validity litigation, not the rule.

82 See, e.g., Microsoft Corp. v. i4i LP, 131 S.Ct. 2238, 2253 (2011) (Breyer, J., concurring) (noting that many important issues in patent law are questions of law to which the clear and convincing evidence standard does not apply).

83 Markman v. Westview Instruments. Inc., 517 U.S. 370 (1996). While the Supreme Court held in Teva Pharms. USA, Inc. v. Sandoz, Inc., 135 S.Ct. 831 (2015) that claim construction could sometimes depend on fact questions, and that appellate courts must defer to a district court's fact-finding when it does, in fact that is rare, because the Federal Circuit usually resolves claim construction by reference to intrinsic evidence, not factual disputes outside the patent. See, e.g., In re Cuozzo Speed Techs., LLC, 793 F.3d 1268 (Fed. Cir. 2015).

84 See Mark D. Janis \& Timothy R. Holbrook, Patent Law's Audience, 97 Minn. L. Rev. 72 (2012).

85 Thus, in Buckingham Prods. Co. v. McAleer Mfg. Co., 108 F.2d 192 (6 ${ }^{\text {th }}$ Cir. 1939), the inventor knew of his own prior public use of the invention. The court estopped him from later invalidating the patent on the basis of that very public use. 
The Rise of Administrative Revocation Proceedings. The third significant change to patent validity determinations is the rise of procedures in the PTO itself for reevaluating the validity of disputed patents. Until 1980, the PTO had no power to revoke patents it decided were improvidently granted. ${ }^{86}$ Beginning in 1980 , Congress has passed a raft of reexamination procedures, including ex parte reexamination, inter partes reexamination, covered business method review, supplemental examination, inter partes review, and post-grant opposition. ${ }^{87}$ Inter partes review in particular has remade the way validity disputes are resolved. Since it was enacted in 2011, challengers have filed several thousand IPR proceedings. ${ }^{88}$ A substantial percentage of all adversarial validity determinations in the last several years have been in IPR or CBM proceedings, not in traditional patent litigation. ${ }^{89}$ Importantly, those challenges can be brought even in circumstances in which the challenger could not file a declaratory judgment action in court. ${ }^{90}$ And the PTO is not bound by even final court determinations on the validity

86 The government could challenge patents, and sometimes did so, but had to go to court to do so. Dolbear v. Am. Bell Tel. Co., 126 U.S. 1, 3 (1888); McCormick Harvesting Mach. Co. v. Aultman, 169 U.S. 606, 612 (1898) ("Had the original patent been procured by fraud or deception it would have been the duty of the Commissioner of Patents to have had the matter referred to the Attorney General with the recommendation that a suit be instituted to cancel the patent ...."). For a discussion, see Mark A. Lemley, Why Do Juries Decide If Patents Are Valid?, 99 Va. L. Rev. 1673 (2013).

87 See 35 U.S.C. $\S \S 302$ et seq. (detailing various mechanisms for reexamination of a patent).

88 www.lexmachina.com (collecting all IPR challenges).

89 See Colleen V. Chien \& Christian Helmers, Inter Partes Review and the Design of Post-Grant Patent Reviews, 19 Stan. Tech. L. Rev. _ (forthcoming 2016) (documenting the growth of the IPR proceeding, and noting that in just the second year of its operation, the PTAB received 1310 IPR requests, a 130 -fold increase over the initial year).

90 The jurisdiction statute provides simply that "a person who is not the owner of a patent" may file an IPR. 35 U.S.C. §311(a). The Federal Circuit has held that parties with no Article III standing can't appeal the denial of their IPR challenge, Consumer Watchdog v. WARF, _ F.3d nothing that prevents those parties from filing the challenge at the PTO. (Fed. Cir. 2015), but there is 
of a patent; it can and regularly does declare a patent invalid even if courts have previously refused to invalidate it. ${ }^{91}$

Assignor estoppel is (probably) an equitable doctrine. ${ }^{92}$ It is applied by courts in their discretion to preclude an argument by defendants where it would seem unfair to allow the defendant to make that argument. It does not create any affirmative right. ${ }^{93}$ It is not clear that judicially-created rules of equity have any application in administrative agency proceedings under the APA. ${ }^{94}$ Equitable defenses are traditionally applied in court only to equitable

91 See, e.g., Fresenius USA, Inc. v. Baxter Int'I, Inc., 721 F.3d 1330 (Fed. Cir. 2013); Ethicon v. Quigg, 849 F.2d 1422, 1428 (Fed. Cir. 1988).

92 The Federal Circuit regularly speaks of assignor estoppel as requiring equitable discretion and the balancing of the equities. See, e.g., Diamond Scientific Co. v. Ambico, Inc., 848 F.2d 1220 (Fed. Cir. 1988) ("Assignor estoppel is an equitable doctrine"); General Foods v. Studiengesellschaft Kohle mbH, 972 F.2d 1272 (Fed. Cir. 1992); Carroll Touch, Inc. v. Electro Mechanical Sys., 15 F.3d 1573 (Fed. Cir. 1993) ("Equity cannot aid the violator of an oath."). So did other courts. See, e.g., Buckingham Prods Co v. McAleer Mfg. Co., 108 F.2d 192 (6 ${ }^{\text {th }}$ Cir. 1939); Faulks v. Kamp. 3 F. 898, 902 (C.C.S.D.N.Y. 1880). But see Diamond Scientific Co. v. Ambico, Inc., 848 F.2d 1220 (Fed. Cir. 1988) ("Assignor estoppel is not governed by the traditional elements of equitable estoppel (or estoppel by conduct) but rather is the functional equivalent of estoppel by deed, which is a form of legal, not equitable, estoppel."); Schuurman et al., supra note _ , at 724 ("The assignor estoppel revived by Diamond Scientific and applied in later patent cases is a de facto form of legal estoppel rather than equitable estoppel").

93 Semiconductor Energy Lab. Co. v. Nagata, 706 F.3d 1365, 1370 (Fed. Cir. 2013).

94 In MCM Portfolio v. Hewlett-Packard Co., _ F.3d__(Fed. Cir. Dec. 2, 2015), the Federal Circuit upheld IPR proceedings against Article III and Seventh Amendment constitutional challenges. The court held that the patent right was a public right, because it "derives from an extensive federal regulatory scheme," and so Article III courts were not required to resolve the dispute, even between private parties. Id. at _. The court held that the IPR was a "quintessential situation in which the agency is adjudicating issues under federal law, Congress having devised an expert and inexpensive method for dealing with a class of questions of fact which are particularly suited to examination and determination by an administrative agency specially assigned to that task." Id. at _. Further, "Congress create[d] new statutory public rights" and "assign[ed] their adjudication to an administrative agency with which a jury trial would be incompatible." $I d$. at _. Thus, "[b]ecause patent rights are public rights, and their validity susceptible to review by an administrative agency, the Seventh Amendment poses no barrier to agency adjudication without a jury." Id. at _. While MCM does not specifically resolve the question of whether the PTO is bound to apply equitable defenses, it makes clear that the PTO is entitled to create and conduct validity proceedings under its own rules, not the rules binding courts. 
remedies, not to legal remedies. ${ }^{95}$ In Spansion v. International Trade Commission, ${ }^{96}$ for example, the Federal Circuit held that the traditional rules of equity the eBay court applied to injunctive relief in patent cases had no application to exclusion orders granted by the International Trade Commission, despite the fact that the ITC enabling statute incorporates both legal and equitable defenses in ITC actions. ${ }^{97}$ By contrast, some state courts have incorporated equitable defenses in administrative proceedings. ${ }^{98}$ While the PTO does employ equitable doctrines in litigation, they are separate doctrines developed in the PTO, not simply applications of judicial equity doctrines. ${ }^{99}$

The existence of administrative revocation proceedings may effectively provide inventors with an end-run around the doctrine of assignor estoppel. The PTAB has refused to apply assignor estoppel in IPR proceedings. ${ }^{100}$ An inventor may therefore be able to bring an administrative challenge even if she would be estopped from bringing the same challenge in

95 Dobbs on Remedies at 105 (defining "an equitable defense, that is, a defense to equitable remedies but not a defense available to bar a claim of legal relief").

96629 F.3d 1331, 1357 (Fed. Cir. 2010).

97 Id.

98 Lentz v. McMahon, 39 Cal.3d 396, 406 (1989); Motley-Motley, Inc. v. State of Washington, http://www.ecy.wa.gov/programs/wr/caselaw/images/pdf/motley motley.pdf, (Wash. Ct. App. 2005). 99 For example, the PTO applies a concept of laches in trademark cases, but that concept is fundamentally different than judicial laches. Judicial laches turns on delay in enforcing a mark, while PTO laches focuses only on delay in bringing an opposition in the PTO. See, e.g., Ava Ruha Corp. v. Mother's Nutritional Center, Inc., http://ttabvue.uspto.gov/ttabvue/ttabvue-92056067-CAN-20.pdf (TTAB Jan. 20, 2015).

100 See, e.g., Esselte Corp. v. Sanford L.P., http://www.patentchallenges.com/wpcontent/uploads/sites/397/2015/10/Esselte.pdf (P.T.A.B. Aug. 28, 2015); Redline Detection LLC v. Star Envirotech, Inc., Case IPR2013-00106 (PTAB June 30, 2014). 
court. Alternatively, she may be able to fund a challenge by a third party. ${ }^{101}$ Or perhaps not. While the Federal Circuit has held that eBay's principles of equity do not bind the ITC, ${ }^{102}$ it has applied assignor estoppel to ITC proceedings. ${ }^{103}$ So there does not appear to be a consistent rule on whether the ITC is bound by judicial doctrines of equity. The application of judicial equitable rules to the PTO may face similar uncertainty.

If inventors or their proxies are able to bring or fund administrative challenges to the validity of the patent, it may ultimately matter less whether they can also raise that challenge as a defense in an infringement action. But it may also make less sense to have a doctrine in a world in which validity challenges are increasingly brought outside of the realm of traditional equity.

\section{The Harm Assignor Estoppel Causes}

The problem with the modern, expanded version of assignor estoppel is not simply that it is out of touch with modern employment relationships and modern patent litigation. An overbroad assignor estoppel doctrine can cause significant harm to the patent system.

\section{Making It Harder to Weed Out Bad Patents}

First, and most obviously, application of the doctrine is likely to make it harder to weed out invalid patents. The Supreme Court has repeatedly emphasized the public benefit from

\footnotetext{
101 If the inventor is the real party in interest she would be barred from raising in litigation a validity challenge she could have raised, but in this case it wouldn't matter since assignor estoppel would bar her from doing so anyway.

102 Spansion Corp. v. ITC, 629 F.3d 1331 (Fed. Cir. 2010).

103 Intel v. ITC, 946 F.2d 821, 837 (Fed. Cir. 1991).
} 
finding and eliminating invalid patents. Lear's rejection of the licensee estoppel doctrine is explicitly based on the importance of weeding out bad patents. ${ }^{104}$ Scott Paper v. Marcalus precluded agreements not to challenge patents. ${ }^{105}$ More recently, in Kimble, the Court refused to overrule a 1964 decision, Brulotte v. Thys, ${ }^{106}$ that prevented parties from agreeing to license payments after a patent expires. In defending the policies behind Brulotte, the Court went out of its way to emphasize the public interest in weeding out invalid patents and the importance of not disabling challenges to those patents:

In a related line of decisions, we have deemed unenforceable private contract provisions limiting free use of such inventions. In Scott Paper Co. v. Marcalus Mfg. Co., 326 U.S. 249 (1945), for example, we determined that a manufacturer could not agree to refrain from challenging a patent's validity. Allowing even a single company to restrict its use of an expired or invalid patent, we explained, "would deprive ... the consuming public of the advantage to be derived" from free exploitation of the discovery. Id., at 256. And to permit such a result, whether or not authorized "by express contract," would impermissibly undermine the patent laws. Id., at 255-256; see also, e.g., Edward Katzinger Co. v. Chicago Metallic Mfg. Co., 329 U.S. 394, 400-401 (1947) (ruling that Scott Paper applies to licensees); Lear, Inc. v. Adkins, 395 U.S. 653, 668-675 (1969) (refusing to enforce a contract requiring a licensee to pay royalties while contesting a patent's validity). ${ }^{107}$

Similarly, in Pope Manufacturing v. Gormully, the Court struck down a promise not to challenge the validity of patents. It reasoned that

It is as important to the public that competition should not be repressed by worthless patents, as that the patentee of a really valuable invention should be protected in his monopoly; and it is a serious question whether public policy permits a man to barter away beforehand his right to defend unjust actions ... With regard to all such matters of public policy, it would seem that no man can

\footnotetext{
104 Lear, Inc. v. Adkins, 395 U.S. 653 (1969).

105326 U.S. 249 (1945).

106379 U.S. 29 (1964).

107 Kimble, 135 S.Ct. at 2407 (citations edited).
} 
bind himself by estoppel not to assert a right which the law gives him on reasons of public policy. ${ }^{108}$

Assignor estoppel makes it harder for society to find and weed out invalid patents.

Because the assignor estoppel doctrine now infects not only the inventor herself but a variety of companies that inventor starts or even goes to work for, and companies that are later bought by those companies, the doctrine of assignor estoppel can bar a number of important competitors from challenging patents.

Relatedly, application of the modern, broad assignor estoppel doctrine will prevent those parties from acknowledging the validity of the underlying invention but challenging overbroad claiming. Much of the problem with patents in many industries is not that there is no invention at all but that patentees are overclaiming the scope of their inventions. ${ }^{109}$ Westinghouse permitted inventors to challenge patent claims that ranged beyond what the inventor actually invented, notwithstanding assignor estoppel. ${ }^{110}$ But the modern doctrine forbids challenge to any patent claim, no matter how far removed from the inventor's actual contribution and no matter how little role the inventor played in drafting the patent or the claim in question. The result is to reduce the likelihood that overbroad claims will be weeded out of patents.

The pendulum is definitely swinging towards weaker patent protection after decades of more expansive protection, and some may worry that we don't need any more ability or

\footnotetext{
108144 U.S. 224, 234-25 (1892).

109 See, e.g., Mark A. Lemley, Software Patents and the Return of Functional Claiming, 2013 Wis. L. Rev. 905; Mark A. Lemley \& Mark P. McKenna, The Scope of IP Rights, _ Wm. \& Mary L. Rev. (forthcoming 2016).

110 Westinghouse Elec. \& Mfg. Co. v. Formica Insulation Co., 266 U.S. 342, 349 (1924).
} 
incentive to weed out bad patents. ${ }^{111}$ And it is correct that challenging patents has costs. But even if you are inclined to oppose any further weakening of the patent system, assignor estoppel seems a bizarre place to draw the line. It is unlikely to reduce the social costs of patent challenges very much, because it particularly privileges invalid patents. It will most likely be used by large companies to bully small start-ups, who will not be able to defend themselves. ${ }^{112}$ And it imposes a particular tax on inventors, placing on them a burden not shared by anyone else in the market.

\section{Restricting Employee Mobility}

Second, the doctrine of assignor estoppel serves effectively as a partial noncompete agreement, preventing inventors from starting new companies or moving to competitors in many circumstances and at least raising the costs of doing so. An inventor cannot start a company or go to work for a competitor in the same area without operating at a significant disadvantage: the inability to effectively defend a patent lawsuit filed against her new company. And that limitation applies not to ideas specifically sold by the inventor to the prior employer, but to any work the employee does that later leads to a patent, with or without her participation.

Worse, the burden of this unbargained-for noncompete falls disproportionately on start-ups. Even with the Federal Circuit's broad privity rules, an inventor who goes to work at a large existing company may not trigger assignor estoppel if she is not a manager and is

111 See, e.g., Mark A. Lemley, The Surprising Resilience of the Patent System, _ Tex. L. Rev. _ (forthcoming 2017) (noting this trend and collecting sources worrying that we are weakening the patent system too much).

112 For a discussion of patent bullying, see Ted Sichelman, The Vonage Trilogy: A Case Study in Patent Bullying, 90 Notre Dame L. Rev. 543 (2014). 
cordoned off from working on projects related to her invention. That itself is socially costly: it requires hiring companies to compartmentalize employees away from their most productive work, and therefore discourages the hiring of inventive employees. ${ }^{113}$ But the situation is worse for start-ups. The same inventor will almost certainly be estopped if she tries to start a new company. ${ }^{114}$ And even if she goes to work for an existing start-up that sort of compartmentalization may be impossible as a practical matter at a new company. Further, the more productive an inventor is - the more different ideas she has - the harder it will be for her to get a job or start a company, as she will have invented in many different fields, making differentiation or compartmentalization more difficult. ${ }^{115}$ The effect is not that of a full noncompete - the inventor is not barred at all from employment in the field. But it raises the costs of hiring an inventor and therefore discourages employee mobility.

Noncompete agreements are disfavored in the law. States have different rules regarding noncompetes. A majority of states permit them but limit them in time and geographic scope, while others ban them entirely. ${ }^{116}$ Companies are using increasingly

\footnotetext{
113 See, e.g., Marc B. Hershovitz, Unhitching the Trailer Clause: The Rights of Inventive Employees and Their Employers, 3 J. Intell. Prop. L. 187, 198-99 (1995) ("business competitors do not desire to hire individuals obligated under such a clause ... At best, employers that hire inventive employees obligated under such agreements will underutilize the employees' inventive skills so as not to develop conflicts with prior trailer clauses."); Lobel, Cognitive Property, supra note _, at 820-21.

114 The doctrine of assignor estoppel may also be behind an otherwise-puzzling Silicon Valley phenomenon: the acqui-hire. Companies often buy start-ups outright when what they really want is just to hire the key engineers at those start-ups. Andres Sawicki suggests that the desire to take the startup's patents may be driving the acqui-hire. Andres Sawicki, Buying Teams, 38 Seattle U. L. Rev. 651 (2015). But while Sawicki envisions the patents being useful assets that improve team production, a more plausible explanation in many circumstances may be that the acquirer wants the patents off the table so they cannot be used against the buyer while it is disabled from challenging their validity.

115 Lobel, supra note _, at 821.

116 See, e.g., Robert P. Merges et al., Intellectual Property in the New Technological Age ch. $2\left(6^{\text {th }}\right.$ ed. 2012).
} 
restrictive noncompetes over time. ${ }^{117}$ But no state permits what the doctrine of assignor estoppel effectively gives - an unbargained-for 20-year noncompete that operates throughout the United States and bars not only the employee but the employee's entire new company from competing with the patent owner using arguably infringing technology. Even states that regularly enforce noncompetes or "trailer clauses" controlling post-employment inventions strictly limit those clauses to short durations after employment ends. ${ }^{118}$ Assignor estoppel does not.

There is strong economic evidence that enforcement of noncompetes interferes with innovation and economic growth. States like California that ban noncompetes have more (and more successful) start-up companies and greater innovation. ${ }^{119}$ Most states other than

117 Norman D. Bishara, Kenneth J. Martin, \& Randall S. Thomas, An Empirical Analysis of Noncompetition Clauses and Other Restrictive Postemployment Covenants, 68 Vand. L. Rev. 1, 2 (2015). But cf. Robert W. Gomulkiewicz, Leaky Covenants-Not-to-Compete as the Legal Infrastructure for Innovation, 49 U.C. Davis L. Rev. 251 (2015) (arguing that companies in Washington state rarely enforce non-competes).

118 For a discussion, see, e.g., Orly Lobel, The New Cognitive Property: Human Capital Law and the Reach of Intellectual Property, 93 Tex. L. Rev. 789, 817-21 (2015); Robert P. Merges, The Law and Economics of Employee Inventions, 13 Harv. J. L. \& Tech. 1, 53 (1999).

119 See, e.g., Mark A. Lemley \& James H.A. Pooley, California Restrictive Employee Covenants After Edwards, 23 California Labor and Employment L. Rev. 3 (2009); Annalee Saxenian, Regional Advantage: Culture and Competition in Silicon Valley and Route 128 (1994); Ronald J. Gilson, The Legal Infrastructure of High Technology Industrial Districts: Silicon Valley, Route 128, and Covenants Not to Compete, 74 N.Y.U. L. Rev. 575, 577-78 (1999); Bruce C. Fallick et al., Job Hopping in Silicon Valley, 88 Rev. Econ. Stat. 472 (2006) (providing empirical support for the Saxenian-Gilson argument); Fredrik Andersson et al., The Effect of HRM Practices and R\&D Investment on Work Productivity. http://web.mit.edu/ipc/sloan05/HRM R\&D Andersson et al.pdf; Rob Valleta, On the Move: California Employment Law and High-Tech Development, Fed. Res. Bank of San Francisco Econ. Ltr. No. 2002-24 (Aug. 16, 2002); On Amir \& Orly Lobel, Driving Performance: A Growth Theory of Noncompete Law, 16 Stan. Tech. L. Rev. 833 (2013); Matt Marx et al., Regional Disadvantage? Non-Compete Agreements and Brain Drain 12-16 (Mass. Inst. Tech. Working Paper, 2010), available at http://ssrn.com/abstract=1654719; Matt Marx, Good Work If You Can Get It ... Again: Non-Compete Agreements, "Occupational Detours," and Attainment16 (Mass. Inst. Tech. Working Paper, 2009), available at http:// ssrn.com/abstract=1456748; Toby Stuart \& Olav Sorenson, Liquidity Events and the Geographic Distribution of Entrepreneurial Activity, 48 Admin. Sci. Q. 175 (2003); Mark Garmaise, Ties that Truly Bind: Noncompete Agreements, Executive Compensation, and Firm Investment, 
California enforce employee covenants not to compete. The fact that California does not enforce them has led to what Alan Hyde has called a "high-velocity labor market": one in which employees can and do change jobs with some frequency. ${ }^{120}$ The ability to leave a job and continue to work in one's chosen profession - something taken for granted in California but subject to significant restrictions elsewhere - obviously benefits employees, who are not bound to bad jobs by fear that they will be unemployable or at least underemployed if they choose to leave. But less obviously, it also benefits employers and the economy as a whole. While employers whose employees want to leave may have a short-term, selfish interest in making it hard for them to do so, those same employers benefit in the long run by being able to hire new employees away from competitors without fear of legal sanction. And perhaps most important, California's rule protecting the freedom of departing employees to compete encourages employees who think they can build a better mousetrap (or a better computer chip or search engine) to start a new company to do just that. ${ }^{121}$

27 J. L., Econ. \& Org. 362 (2011). But see Gomulkiewicz, supra note _, at 251 (arguing that Washington state is innovative despite having noncompetes, in part because companies there rarely enforce them). Gomulkiewicz suggests that noncompetes should be enforced only in circumstances where they prevent the theft of trade secrets. Id. at 290-91. But trade secret law is independent of noncompete law, and states like California that do not enforce noncompetes will nonetheless enforce trade secrets.

A recent paper by Jonathan Barnett and Ted Sichelman challenges some of this empirical work on a variety of methodological grounds. Jonathan M. Barnett \& Ted Sichelman, Revisiting Labor Mobility in Innovation Markets 14-30 (working paper 2016). Notably, however, even they do not find evidence that restricting employee mobility encourages innovation; at most, they conclude that the studies (essentially all of which point in the opposite direction) cannot demonstrate causation or can show it only in certain industries, like information technology. $I d$. at 35-36, 51-53.

120 Alan Hyde, Working in Silicon Valley: Economic and Legal Analysis of a High-Velocity Labor Market (2003).

121 Orly Lobel, Talent Wants to be Free: Why We Should Learn to Love Leaks, Raids, and Free Riding (2013); Lemley \& Pooley, supra note _. Cf. Michal Shur-Ofry, Access to Error, _ Cardozo Arts \& Ent. L.J. _ (forthcoming 2016), available at http://papers.ssrn.com/sol3/papers.cfm?abstract id=2693464 
By acting as an effective (and overbroad) noncompete that specifically targets start-ups, the doctrine of assignor estoppel reduces employee mobility and likely therefore reduces the number and speed with which new technologies are deployed. ${ }^{122}$ Because it is mandatory federal patent policy, it overrides the choice of states like California to encourage employee mobility. It is a most peculiar rule in a society overwhelmingly devoted to encouraging and celebrating innovation - a doctrine that singles out innovators for punishment. ${ }^{123}$

\section{A Continued Role for Assignor Estoppel?}

\section{A. Bringing Assignor Estoppel Back to Its Roots}

Given the problems with the modern doctrine of assignor estoppel, one possible solution is to abolish the doctrine altogether. The Supreme Court has already struck down the licensee estoppel doctrine and no-challenge clauses without obvious ill effect on patent

(arguing that innovation requires access to "negative know-how" that is often locked up in trade secrets and noncompetes).

While advocates for noncompetes worry that the employer won't capture the full value of the employee's idea, reducing the incentive to invest in training employees, economic research has shown that these "spillovers" are actually good, not bad, for innovation. See, e.g., Brett M. Frischmann \& Mark A. Lemley, Spillovers, 107 Colum. L. Rev. 257 (2007); Dietmar Harhoff, R\&D Spillovers, Technological Proximity, and Productivity Growth-Evidence from German Panel Data, 52 Schmalenbach Bus. Rev. 238, 258 (2000) ("High-technology firms react more sensitively to spillovers in terms of their R\&D spending, and their direct marginal productivity gain from spillovers (in excess to the effect from enhanced R\&D spending) is considerably larger than the respective gain for less technology-oriented firms."). Indeed, the positive relationship is so strong that some economists use spillovers as a measure of innovation! See Tobias Schmidt, An Empirical Analysis of the Effects of Patent and Secrecy on Knowledge Spillovers 1 (Ctr. for Eur. Econ. Res., Discussion Paper No. 06-048, 2006), available at ftp://ftp.zew.de/pub/zew-docs/dp/dp06048.pdf.

122 As Franklin Ubell explains, "[e]x-employees are a considerable source of new competition and new business ventures." Franklin D. Ubell, Assignor Estoppel: A Wrong Turn from Lear, 71 J. Pat. \&

Trademark Ofc. Soc'y 26, 26 (1989). But see Hatfield, supra note _, at 273 (arguing for per se application of the doctrine of assignor estoppel in order to increase employer incentives, regardless of the harm to employee interests).

123 Lobel, Cognitive Property, supra note , at 820. 
incentives. Abolishing the assignor estoppel doctrine would seem consistent with those decisions. Indeed, given the Federal Circuit's "contrived and unwarranted . . . unjustified aboutface" from Supreme Court precedent, ${ }^{124}$ it is likely that the Court will overrule current Federal Circuit doctrine if and when the issue is presented to it. ${ }^{125}$

But there is a kernel of wisdom at the heart of the assignor estoppel doctrine. And that kernel of wisdom offers a possible, albeit limited, continued role for the doctrine. As it was originally conceived, the doctrine was limited to circumstances in which the inventor sold the patent to the assignee as valuable, made factual representations about the validity of that patent, and then contradicted those representations when it was in its interest to do so. ${ }^{126}$ The analogy of estoppel by deed seems to require these elements. When all of those things are true, it does seem inequitable for the inventor to change her position when it benefits her to do so. It may also raise questions as to whether she was lying then (when she represented that the patent was valid) or is lying now. ${ }^{127}$

The modern assignor estoppel doctrine has eliminated each of those factors as a requirement for asserting the doctrine. Today, the doctrine applies to employee work that is automatically assigned to the company without any representation by the employee at all. Indeed, the company can file a patent in the employee's name without their participation at

\footnotetext{
124 Hodgson, supra note _, at 813, 815.

125 Hodgson points out that in reestablishing the doctrine in Diamond Scientific, the Federal Circuit cited to Justice Frankfurter's dissent in Scott Paper, not to the majority opinion. Id. at 817.

126 Westinghouse Elec. \& Mfg. Co. v. Formica Insulation Co., 266 U.S. 342, 349 (1924).

127 Cooper, Estoppel to Challenge Patent Validity: The Case of Private Good Faith vs. Public Policy, 18 W.
} Res. L. Rev. 1122, 1131 (1967). 
all. ${ }^{128}$ Those employees may not make any representations at all, much less representations about facts in their possession that affect the validity of the patent. Other inventors may actually sell the patent for value. The application of assignor estoppel to those inventors may make more sense. But even then there seems little reason to estop them from later making legal arguments that do not depend on any factual information provided by the inventor. It is only when an inventor makes a factual representation that drives the patenting of the invention and sells her rights in exchange for money that estoppel should apply.

A second possible justification for a limited form of assignor estoppel may be a worry that interested inventors will concoct false factual claims to try to defeat their patents, and that those claims will have particular force for a jury because the inventor is seen to be testifying against their own interest by denigrating their own invention. This justifies assignor estoppel only as applied to inventor testimony, particularly inventor testimony that makes a factual claim that is within the inventor's unique knowledge. Preventing that testimony may sometimes cause us to let invalid patents through, but it is reasonable to worry that allowing that testimony has the potential to do greater harm.

There are reasons, then, to retain the doctrine of assignor estoppel. But they are limited to very specialized circumstances that don't come up all that often in modern patent litigation. There is a simple way to align the law with good policy: roll back the doctrine of assignor estoppel to where it was when the Supreme Court decided Lear or at least Westinghouse. That doctrine would bind inventors and those who work with them to the representations they affirmatively made, but not to some broader promise that anything they

12835 U.S.C. $\$ 116$. 
invented must have led to a valid patent. It might also prevent inventors from testifying to facts solely in their possession that would render the patent invalid or unenforceable. It should not prevent validity challenges not based on those representations. Nor should it bind companies who can find evidence other than inventor testimony on which to base their validity challenge.

\section{B. Estoppel by Contract?}

If the courts are to restrain the application of assignor estoppel, the question then becomes whether parties can contract for the application of the doctrine in circumstances in which it would not otherwise apply. If so, all companies might be expected to do so along with their invention assignment agreements, and it might not seem as though much has changed.

It is not clear that parties will or should be permitted to contract for the application of assignor estoppel. In the wake of the Lear decision striking down the doctrine of licensee estoppel, the circuits that confronted efforts to reestablish estoppel by contract generally held that this was a mandatory rule, not a default rule. ${ }^{129}$ That view gained considerable support when the Supreme Court decided Medlmmune v. Genentech, ${ }^{130}$ holding that a licensee could challenge a patent without repudiating the license. The license in question prohibited such a payment, but the Court disregarded that fact. ${ }^{131}$ While it did not hold that a contract could not avoid licensee estoppel - it didn't recognize or discuss the issue - that seems a fair implication of the outcome. Given the parallels between assignor and licensee estoppel, it is at least

\footnotetext{
129 Cites.

130 Medlmmune, Inc. v. Genentech, Inc., 549 U.S. 118 (2007).

131 Id. at
} 
plausible that courts will hold that the scope of assignor estoppel cannot be varied by contract. After all, the Federal Circuit currently permits contracts that limit assignor estoppel only in "extraordinary circumstances." ${ }^{132}$ It's not obvious the result should be any different for contracts that seek to expand assignor estoppel.

Even if courts were to permit contracting into assignor estoppel, the result would still be significantly narrower than the modern version of the doctrine. The contract would bind only those in privity with the assignee. The inventor herself might be bound not to bring a challenge or perhaps to testify against the patent, and that contract might plausibly extend to a new company that inventor founded. But it would not extend down the chain of privity to new employers, new companies those employers buy, people who worked with the inventor at a new company, or the rest. And because new employers would not be bound by the contract, a contract to create estoppel would reduce, though not eliminate, the extent to which estoppel interferes with employee mobility. ${ }^{133}$

To be clear, I think the courts should not permit an employment agreement contract into assignor estoppel. And I think that is the result courts would likely reach, just as they did for licensee estoppel after Lear. But even were courts to conclude otherwise, the limitations of contract rather than federal patent policy mean that assignor estoppel by contract would impose far less of a limit on employee mobility and efforts to challenge bad patents that current law does.

\footnotetext{
132 Mentor Graphics, 150 F.3d at _..

133 A contract approach would also operate as a matter of state, not federal, law, meaning that a state like California particularly concerned with employee mobility would be able to prevent such contracting.
} 


\section{Conclusion}

As one commentator puts it, "tension exists between the present construction of assignor estoppel and Supreme Court precedent." ${ }^{134}$ Others are more blunt, reading the Federal Circuit as having expressly revived a doctrine that the regional circuits had treated as dead at least since Lear. ${ }^{135}$ And where the Federal Circuit has systematically departed from Supreme Court doctrine in the past, the ultimate result has been that the Supreme Court rejects those cases and brings the law back in line with its prior decisions. ${ }^{136}$ Doing so is consistent with subsequent Supreme Court decisions emphasizing the importance of challenging invalid patents. It is consistent with the limits states put on noncompete agreements. And it is consistent with the underlying principles of equity that drove the doctrine in the first place. Returning assignor estoppel to its equitable roots strikes the right balance between fairness and protecting the public interest in patent validity and employee mobility. If and when the Supreme Court takes its next look at assignor estoppel, that is likely exactly what it will do.

\footnotetext{
134 Steinberg \& Chavous, supra note _..

${ }^{135}$ Willem G. Schuurman et al., Assignor Estoppel: Infringement, Inequitable Conduct, and Privity in Light of Diamond Scientific and Shamrock Technologies, 72 J. Pat. \& Trademark Ofc. Soc'y 723, 723-24 (1990). See also id. at 725 (referring to the doctrine as "discredited and virtually buried" until the Federal Circuit's "abrupt turn" in Diamond Scientific).

136 See, e.g., Alice Corp Pty., Ltd. v. CLS Bank Int'I, 134 S.Ct. 2347 (2014); KSR Int'I Co. v. Teleflex, Inc., 550 U.S. 398 (2007); MedImmune, Inc. v. Genentech, Inc., 549 U.S. 118 (2007).
} 